\title{
Problematika Penyelesaian Perkara Tindak Pidana Politik Uang (Money Politic) dalam Pemilihan Umum
}

\author{
Ramon Azmi Pratama; Dheny Wahyudi \\ Fakultas Hukum Universitas Jambi \\ Author's email correspondence: ramonazmipratama.ra10@gmail.com
}

\begin{abstract}
ABSTRAK
Permasalahan politik uang dalam pesta demokrasi (Pemilu) merupakan tindakan yang kerap terjadi. Isu ataupun memang benar nyata terjadi, setidaknya mengharuskan ruang pikir bagaimana dengan aturan hukum yang ada, yang mengatur hal tersebut, serta bagaimana sebenarnya alur penyelesaian tindakan tersebut. Penelitian ini bertujuan untuk mengetahui proses penanganan perkara tindak pidana politik uang yang ditangani pada Badan Pengawas Pemilu (Bawaslu) Provinsi Jambi pada Pemilu 2019 dan fakor penghambat penanganan tindak pidana tersebut. Adapun hasil penelitian, bahwa proses penanganan tindak pidana politik uang pada Pemilu 2019 melalui sembilan tahap yang setiap tahap dibatasi waktu yaitu, Tahap temuan dan laporan, pembahasan pertama di Sentra Gakkumdu, pembahasan kedua di Sentra Gakkumdu, rapat pleno, tahap penyidikan, pembahasan ketiga di Sentra Gakkumdu, tahap penuntutan, tahap pengadilan, dan pembahasan keempat di Sentra Gakkumdu. Faktor penghambat dalam penanganan tindak pidana politik uang, yaitu pengaturan alur penanganan yang panjang dengan waktu yang terbatas, sulitnya menemukan alat bukti karena waktu terlalu singkat.
\end{abstract}

\section{ARTICLE HISTORY}

Submission: 2020-06-11

Accepted: 2020-10-07

Publish: 2020-10-10

KEYWORDS: Elections; Money politics.
Kata Kunci: Pemilu; Politik

uang.

\section{ABSTRACT}

The problem of money politics in democratic parties (elections) is an act that often occurs. The issue, or indeed it really happened, at least requires a space to think about how the existing legal rules, which regulate it, as well as how exactly the flow of completion of the action. This study aims to determine the process of handling cases of money politics criminal acts handled by the Election Supervisory Body (Bawaslu) of Jambi Province in the 2019 Election and the factors which hamper the handling of these criminal acts. As for the results of the study, that the process of handling money politics in 2019 Election through nine stages, each phase limited by time, namely, the stages of findings and reports, the first discussion at the Gakkumdu Center, the second discussion at the Gakkumdu Center, the plenary meeting, the investigation stage, the third discussion at Gakkumdu Center, the prosecution stage, the court stage, and the fourth discussion at the Gakkumdu Center. Inhibiting factors in handling money politics crime, namely setting a long flow of handling with limited time, difficulty in finding evidence because the time is too short. 


\section{A. PENDAHULUAN}

Pemilu yang diselenggarakan pada tanggal 17 April 2019 menyoroti tindak pidana politik uang dalam pemilu, hal ini dapat dilihat dalam berbagai diskusi di beberapa Seminar dan media Televisi Nasional yang diadakan mulai dari sebelum pelaksanaan pemilu. Bahkan sebelum pelaksanaan pemilu, Badan Pengawas Pemilu (Bawaslu) Repubik Indonesia angkat bicara soal politik uang(money politics). Anggota Bawaslu RI Ratna Dewi Pettalolo mengatakan: “Undang-Undang Nomor 7 Tahun 2017 Tentang Pemilihan Umum hanya mengatur larangan politik uang terbatas pada waktu dan objek." ${ }^{1}$ Celah pada aturan tersebut mungkin akan dimanfaatkan oleh orang yang melakukan politik uang. Pasal tentang politik uang yang hanya membatasi waktu dan objek diatur dalam Undang-Undang Nomor 7 Tahun 2107 Tentang Pemilhan Umum (selanjutnya disebut Undang-Undang Pemilu) dirumuskan dalam Pasal 515 dan Pasal 523 Ayat (1), Ayat (2), dan Ayat (3).

Dalam proses penanganan tindak pidana Pemilu juga dibatasi oleh waktu, mulai dari proses laporan dan temuan di Bawaslu, tahap penyelidikan, tahap penyidikan, tahap penuntutan,sampai pada tahap pemerikasaan, mengadili dan memutuskan di pengadilan yang diatur dalam Undang-Undang Pemilu. Ditahap Bawaslu dalam memproses perkara tindak pidana pemilu harus meneruskan laporan dan temuannya kepada Kepolisan Negara Republik Indonesia dalam waktu satu hari. Hal ini di atur dalam Pasal 476 Ayat (1) yang menentukan:

Laporan dugaan tindak pidana Pemilu diteruskan oleh Bawaslu, Bawaslu Provinsi, Bawaslu Kabupaten/Kota,dan/atau Panwaslu Kecamatan kepada Kepolisian Negara Republik Indonesia paling lama 1 x 24 (satu kali dua puluh empat) jam sejak Bawaslu Kabupaten/Kota,dan/atau Panwaslu Kecamatan menyatakan bahwa perbuatan atau tindakan yang diduga merupakan tindak pidana Pemilu.

Ditahap Penyelidikan, Penyelidik harus menemukan bukti permulaan yang cukup dalam waktu satu hari. Hal ini diatur dalam Pasal 479 yang menyatakan: "Penyelidik dalam melakukan Penyelidikan menemukan bukti permulaan yang cukup adanya dugaan tindak pidana Pemilu, hasil Penyelidikannya disertai berkas perkara disampaikan kepada penyidik paling lama 1 x 24 (satu kali dua puluh empat) jam".

Ditahap Penyidik, Polisi harus menyampaikan penyidikannya paling lama 14 (empat belas) hari di sertai berkas perkara kepada Penuntut Umum, hal ini di atur dalam Pasal 480 Ayat (1), dilanjutkan dalam rumusan Ayat (2) menentukan: "jika hasil penyidikan belum lengkap, Penuntut Umum harus mengembalikan berkas perkara kepada Kepolisian paling lambat tiga hari”, kemudian di ayat (3) diatur dalam waktu tiga hari setelah berkas dikembalikan, penyidik Kepolisian harus menyampaikan kembali kembali berkas perkara kepada Penuntut Umum. Sedangkan jangka waktu yang diberikan kepada Penuntut Umum untuk melimpahkan berkas ke Pengadilan Negeri paling lama lima hari berdasarkan Pasal 480 Ayat 4.

1 https://tirto.id/bawaslu-akui-ada-celah-politik-uang-di-pemilu-2019-c9oH, Diakses pada tanggal 14 September 2019. 
Dalam proses memeriksa, mengadili, dan memutus perkara tindak pidana pemilu di pengadilan negeri juga dibatasi waktu berdasarkan Pasal 482 Ayat (1) yang menentukan: "Pengadilan Negeri memeriksa, mengadili, dan memutus perkara tindak pidana Pemilu paling lama 7 (tujuh) hari setelah pelimpahan berkas perkara dan dapat dilakukan dengan tanpa kehadiran terdakwa".

Berbeda dengan perkara pada umumnya, tindak pidana Pemilu hanya sampai pada tingkat banding di Pengadilan Tinggi. Sesuai dengan Pasal 482 Ayat (5) yang mengatakan bahwa: "putusan Pengadilan Tinggi merupakan putusan terakhir dan mengikat serta tidak dapat dilakukan upaya hukum lain".

Terbatasnya waktu dalam proses penanganan tindak pidana Pemilu tentunya akan berpengaruh pada tercapainya tujuan dan guna pembuktian. Tujuan dan guna pembuktian adalah sebagai berikut:

a. Bagi Penuntut Umum, pembuktian merupakan usaha untuk meyakinkan hakim yakni berdasarkan alat bukti yang ada, agar menyatakan seorang terdakwa bersalah sesuai dengan surat atau catatan dakwaan.

b. Bagi Terdakwa atau penasihat hukum, pembuktian merupakan usaha sebaliknya, untuk meyakinkan hakim yakni berdasarkan alat bukti yang ada, agar menyatakan terdakwa dibebaskan atau dilepaskan dari tuntutan hukum atau meringankan pidananya. Untuk itu terdakwa atau penasihat hukum jika mungkin harus mengajukan alat-alat bukti yang menguntungkan atau meringankan pihakpihaknya. Biasanya bukti tersebut disebut bukti kebalikannya.

c. Bagi Hakim atas dasar pembuktian tersebut yakni dengan adanya alat-alat bukti yang ada dalam persidangan baik yang berasal dari penuntut umum atau penasihat hukum/terdakwa dibuat dasar untuk membuat keputusan. ${ }^{2}$

Dibatasinya objek dan waktu dalam proses penanganan tindak pidana pemilu khususnya politik uang mengakibatkan bawaslu mengalami kesulitan dalam memproses temuan dan laporan mereka tentang politik uang(money politics). Kesulitan dalam proses penanganan perkara tindak pidana politik uang juga dialami Bawaslu Provinsi Jambi. Berdasarkan catatan laporan dan temuan Bawaslu Provinsi Jambi periode laporan 18 Mei 2019 tercatat 9 (Sembilan) kasus Politik uang yang semuanya itu prosesnya dihentikan sebelum sampai ke Pengadilan. Sembilan kasus politik uang di Provinsi Jambi dapat kita lihat pada tabel di bawah ini:

2 Hari Sasangka dan Lily Rosita, Hukum Pembuktian dalam Perkara Pidana, Mandar Manju, Surabaya, 2003, hlm 13. 
Tabel

Status Penanganan Tindak Pidana Politik Uang

di Bawaslu Provinsi Jambi pada Pemilu 2019.

\begin{tabular}{|c|c|c|c|c|}
\hline No. & Kab./Kota & $\begin{array}{c}\text { Nomor } \\
\text { Temuan/La } \\
\text { poran }\end{array}$ & $\begin{array}{c}\text { Nomor } \\
\text { Register }\end{array}$ & Status Penanganan \\
\hline 1. & Batanghari & $\begin{array}{l}01 / \mathrm{LP} / \mathrm{PL} / \mathrm{Ka} \\
\mathrm{b} / 05.03 / \mathrm{IV} / 2 \\
019\end{array}$ & $\begin{array}{c}01 / \mathrm{LP} / \mathrm{PL} / \\
\mathrm{Kab} / 05.03 / \\
\mathrm{IV} / 2019\end{array}$ & $\begin{array}{c}\text { dihentikan pada Pembahasan } \\
\text { kedua Gakkumdu karena } \\
\text { kurangnya alat bukti }\end{array}$ \\
\hline 2. & Sarolangun & $\begin{array}{c}003 / \mathrm{TM} / \mathrm{PL} / \\
\mathrm{KAB} / 05.08 / \mathrm{X} \\
\mathrm{II} / 2018 \\
\end{array}$ & $\begin{array}{c}003 / \mathrm{TM} / \mathrm{PL} \\
/ \mathrm{KAB} / 05.08 \\
/ \mathrm{XII} / 2018\end{array}$ & $\begin{array}{l}\text { Dihentikan pada Pembahasan } \\
\text { I di Sentra Gakkumdu karena } \\
\text { tidak terdapat cukup bukti }\end{array}$ \\
\hline \multirow[t]{2}{*}{3.} & \multirow[t]{2}{*}{ Sungai Penuh } & $\begin{array}{l}\text { 04/TM/PL/K } \\
\text { OTA/05.02/I } \\
\text { V/2019 }\end{array}$ & $\begin{array}{l}04 / \mathrm{TM} / \mathrm{PL} / \\
\text { KOTA/05.0 } \\
2 / \mathrm{IV} / 2019\end{array}$ & $\begin{array}{c}\text { Dihentikan karena tidak } \\
\text { adanya alat bukti yang cukup } \\
\text { untuk dinaikkan } \\
\text { kepenyidikan pada tahap } 2 \\
\text { sentra Gakkumdu }\end{array}$ \\
\hline & & $\begin{array}{c}\text { 05/TM/PL/K } \\
\text { OTA/05.02/I } \\
\text { V/2019 } \\
\end{array}$ & $\begin{array}{l}05 / \mathrm{TM} / \mathrm{PL} / \\
\text { KOTA/05.0 } \\
2 / \mathrm{IV} / 2019 \\
\end{array}$ & $\begin{array}{c}\text { Dihentikan pada Pembahasan } \\
\text { I karena tidak ada bukti awal } \\
\text { yang cukup }\end{array}$ \\
\hline \multirow[t]{2}{*}{4.} & \multirow[t]{2}{*}{ Tebo } & $\begin{array}{l}\text { 01/LP/PILEG } \\
\text { /TEBO/05.11 } \\
\text { /VIII/2018 }\end{array}$ & $\begin{array}{l}\text { 01/LP/PILE } \\
\text { G/TEBO/05. } \\
\text { 11/VIII/201 } \\
8\end{array}$ & $\begin{array}{c}\text { Dihentikan pada pembahasan } \\
\text { Tahap } 2 \text { (tanggal } 4 \text { Januari } \\
\text { 2019) karena dugaan tindak } \\
\text { pidana pemilu tesebut tidak } \\
\text { memenuhi unsur tindak } \\
\text { pidana pemilu berdasarkan } \\
\text { Undang-undang Nomor } 7 \\
\text { Tahun } 2017 \text { tentang } \\
\text { Pemilihan Umum Pasal } 454 \\
\text { ayat } 6 .\end{array}$ \\
\hline & & $\begin{array}{l}\text { 01/LP/PILEG } \\
\text { /TEBO/05.11 } \\
/ \text { IV/2019 }\end{array}$ & $\begin{array}{l}\text { 01/LP/PILE } \\
\text { G/TEBO/05. } \\
\text { 11/IV/2019 }\end{array}$ & $\begin{array}{c}\text { Dihentikan pada pembahasan } \\
\text { kedua bersama Tim } \\
\text { Gakkumdu Bawaslu } \\
\text { Kabupaten Tebo karena tidak } \\
\text { memenuhi unsur Tindak } \\
\text { Pidana Pemiu }\end{array}$ \\
\hline 5. & Tanjab Barat & $\begin{array}{l}\text { 01/TM/PL/K } \\
\mathrm{ab} / 05.09 / \mathrm{II} / \\
2019\end{array}$ & $\begin{array}{l}\text { 01/TM/PL/ } \\
\text { Kab/05.09/ } \\
\text { II/2019 }\end{array}$ & $\begin{array}{c}\text { Dihentikan pada pembahasan } \\
\text { tahap } 1 \text { (Tanggal 09 Maret } \\
\text { 2019) karena tidak } \\
\text { memenuhi unsur }\end{array}$ \\
\hline 6. & Tanjab Timur & $\begin{array}{l}\text { 02/LP/PL/Ke } \\
\text { c. (Nipah } \\
\text { Panjang)/05. } \\
\text { 10/IV/2019 }\end{array}$ & $\begin{array}{l}\text { 02/LP/PL/ } \\
\mathrm{Kab} / 05.10 / \\
\mathrm{IV} / 2019\end{array}$ & $\begin{array}{l}\text { Hasil Pembahasan Sentra } \\
\text { Gakkumdu Kab. Tanjung } \\
\text { Jabung Timur tahap } 2 \text { karena } \\
\text { tidak Memenuhi Unsur pasal } \\
523 \text { Undang-Undang No } 7 \\
\text { Tahun } 2017 \text { Tentang }\end{array}$ \\
\hline
\end{tabular}




\begin{tabular}{|c|l|c|c|c|}
\hline & & & & Pemilihan Umum. \\
\hline 7. & Kerinci & 01/TM/PL/K & 01/TM/PL/ & Dihentikan pada pembahasan \\
& & ab/05.05/XII & Kab/05.05/ & tahap 2 (tanggal 15 Januari \\
& & $/ 2018$ & XII/2018 & 2019) karena Tidak \\
& & & $\begin{array}{c}\text { Memenuhi Unsur Tindak } \\
\text { Pidana Pemilu }\end{array}$ \\
\hline & & & 9 Kasus Dihentikan \\
\hline
\end{tabular}

Sumber data: Bawaslu Provinsi Jambi

Menurut penulis dari 9 (sembilan) kasus ada 4 (empat) diantaranya dapat dinaikan ke tahap selanjutnya. Kasus yang dapat dinaikan ke tahap selanjutnya menurut penulis sebagai berikut:

1. Di Batanghari berdasarkan uraian peristiwa dari Bawaslu Provinsi Jambi Pada hari Sabtu tanggal 13 April 2019 sekitar Pukul 19.30 WIB salah satu Caleg DPR RI melakukan Kampanye Pertemuan Terbatas di salah satu Rumah Warga, kemudian dalam kegiatan kampanye tersebut Tim dari Caleg DPR RI membagikan amplop yang berisi uang sebesar Rp25.000,00 (dua puluh lima ribu rupiah) kepada warga yang datang pada kegiatan tersebut.

2. Di Tebo berdasarkan uraian peristiwa dari Bawaslu Provinsi Jambi Pada hari Senin tanggal 15 April 2019 Pukul 22.30 WIB ada pembagian uang agar memilih ke salah satu Caleg, dengan Jumlah uang Rp. 1.000.000 kemudian pelapor melakukan perekaman suara dimana salah satu warga mengakui bahwa uang tersebut di dapatkan dari salah satu Tim Pemenangan Caleg

3. Di Tanjung Jabung Barat berdasarkan uraian peristiwa Bawaslu Provinsi Jambi Dugaan Politik Uang Pada masa Kampanye, salah satu Caleg melakukan kampanye Tatap Muka dengan Penyampaian Materi Terkait Cara mencoblos Surat Suara. Selanjutnya PPKD Desa tersebut peserta Kampanye Menerima Satu buah Amplop yang berisikan uang Sejumlah Rp 30.000 (Tiga Puluh Ribu Rupiah) yang dijadikan Barang Bukti dan Disita oleh Panwascam Tebing Tinggi.

4. Di Kerinci berdasarkan uraian peristiwa Bawaslu Provinsi Jambi Pada tanggal 20 Desember 2019, dilaksanakan kampanye tatap muka salah satu calon anggota DPR RI. Panwaslu kecamatan melakukan pengawasan di tempat kampanye tersebut dan melihat adanya pembagian amplop kepada peserta kampanye, diduga amplop tersebut berisi uang yang mana pemberian uang tersebut bermaksud untuk memilih caleg pada saat pemungutan suara.

Dari uraian peristiwa di atas penulis berpendapat bahwa perkara tersebut bisa dinaikan ke tahap selanjutnya jika di beri waktu lebih untuk mencari alat bukti.

Oleh karena itu dalam artikel ini akan di angkat permasalahan proses penanganan perkara tindak pidana politik uang pada pemilu 2019 dan faktor apa saja yang menghambat proses penanganan tindak pidana politik uang pada pemilu 2019.

\section{B. METODE PENELITIAN}

Penelitian ini merupakan penelitian Yuridis Empiris. Penelitian ini mengkaji proses penanganan perkara tindak pidana politik uang pada pemilu 2019 dan faktor penghambat penanganan perkara tindak pidana politik uang pada pemilu $2019 \mathrm{di}$ wilayah hukum Badan Pengawas Pemilu (Bawaslu) Provinsi Jambi. 


\section{PEMBAHASAN}

\section{Proses Penanganan Perkara Tindak Pidana Politik Uang (Money Politic) Pada Pemilu 2019 Di Wilayah Hukum Bawaslu Provinsi Jambi}

Pemilu tahun 2019 terdapat kasus tindak pidana pemilu, tidak terkecuali dalam tindak pidana politik uang. Memberi materi kepada pemilih agar memilih calon tertentu telah merusak Demokrasi di Indonesia. Di Provinsi Jambi saja terdapat 9 (sembilan) temuan dan laporan yang tercatat di Bawaslu Provinsi Jambi meskipun semua kasus tersebut dihentikan sebelum sampai Pengadilan. Hal ini juga disampaikan Bapak Asnawi R, M.Pd., sebagai Ketua Bawaslu Provinsi Jambi, "Pemilu 2019 memang ada beberapa kasus politik uang yang ditangani di bawaslu di kabupaten/kota wilayah provinsi Jambi, namun tidak ada satu kasus pun sampai ke pengadilan. Karena menurut Sentra Gakkumdu yang menangani kasus politik uang itu masih kekurangan alat bukti".3

Dalam proses penanganan perkara tindak pidana Pemilahan Umum Tahun 2019 terkesan tidak transparan dengan dikeluarkannya Penetapan Pejabat Pengelola Informasi dan Dokumentasi Badan Pengawas Pemilihan Umum Nomor 0015/BAWASLU/H2PI/HM.00/I/2019 Tentang Informasi Dugaan Tindak Pidana Pemilihan Umum yang dikecualikan, yang berisi informasi yang dikecualikan sebagai berikut:

1. Ceklist laporan/temuan dugaan tindak pidana pemilu.

2. Berita acara pembahasan pertama sentra Gakkumdu (SG1).

3. Laporan hasil penyelidikan dugaan tindak pidana pemilu.

4. Berita acara pembahasan kedua Sentra Gakkumdu (SG2).

5. Penerusan pelanggaran pemilu ke penyidikan.

6. Daftar saksi dan/atau ahli.

7. Daftar tersangka.

8. Daftar barang bukti.

9. Laporan polisi.

10. Tanda bukti laporan.

11. Berita acara pembahasan Sentra Gakkumdu (SG3).

12. Pengembalian berkas penuntut ke penyidik.

13. Pemberitahuan berkas lengkap dari penyidik ke penuntut.

Dengan adanya informasi yang dikecualikan di atas menurut penulis Bawaslu tidak transparan dalam menangani perkara tindak pidana pemilu sehingga masyarakat hanya mengetahui status penanganan perkara tersebut tanpa mengetahui detail kenapa perkara tersebut dihentikan ataupun naik ke proses selanjutnya.

Proses penanganan perkara sangat penting dalam menentukan apakah suatu peristiwa termasuk kategori tindak pidana atau bukan. Tindak pidana pemilu dalam Peraturan Bawaslu Nomor 7 Tahun 2018 Tentang Penanganan Temuan dan Laporan Pelanggaran Pemilu menjelaskan bahwa: "Tindak pidana pemilu adalah tindak pidana pelanggaran dan/atau kejahatan terhadap ketentuan tindak pidana pemilu sebagaimana diatur dalam undang-undang tentang pemilahan umum". Penulis disini tidak membahas tindak pidana pemilu secara keseluruhan, tetapi lebih

3 Wawancara dengan Asnawi R, Ketua Bawaslu Provinsi Jambi, tanggal 5 Desember 2019. 
mengkhususkan pada tindak pidana politik uang di wilayah hukum Bawaslu Provinsi Jambi. Menentukan apakah seseorang benar telah melakukan tindak pidana politik uang atau bukan sangat penting dalam mewujudkan salah satu asas pemilu yaitu jujur dan adil, sebagaimana yang telah diatur dalam Pasal 2 Undang-Undang Nomor 7 Tahun 2017 Tentang Pemilihan Umum yang menentukan "Pemilu dilaksanakan berdasarkan asas langsung, umum, bebas, rahasia, jujur dan adil”.

Selanjutnya oleh Wein Arifin sebagai Koordinaor Devisi Penindakan Pelanggaran Bawaslu Provinsi Jambi menjelaskan:

Proses penanganan perkara tindak pidana politik uang secara umum sama dengan proses pembuktian tindak pidana lainnya yang diatur dalam Kitab Undang-Undang Hukum Acara Pidana (KUHAP) hanya saja ada beberapa kekhususan dalam penanganan tindak pidana pemilu yang diatur dalam Undang-Undang Nomor 7 tahun 2017 tentang pemilahan umum dan Peraturan Bawaslu Republik Indonesia Nomor 7 tahun 2018 tentang penanganan temuan dan laporan pelenggaran pemilahan umum. Proses penanganan perkara tindak pidana politik uang pada pemilu 2019 yang baru saja diselenggarakan ada sembilan (9) tahap, yaitu (1) Adanya Temuan dan Laporan; (2) Gakkumdu melakukan Pembahasan Pertama; (3) kemudian dilanjut dengan Pembahasan kedua di Gakkumdu; (4) Rapat Pleno ; (5) Penyidikan; (6) Pembahasan ketiga di Gakkumdu; (7) Penuntutan ; (8) Pengadilan; (9) Pembahasan Keempat di Gakkumdu. 4

Berdasarkan uraian diatas maka perlunya diketahui proses pembuktian dan faktor penghambat dihentikannya proses pembuktian tindak pidana politik uang, sebagai berikut.

Berdasarkan penjelasan Ketua Bawaslu dan Koordinator Devisi Penindakan Pelanggaran Bawaslu Provinsi Jambi, dapat diuraikan mengenai proses pembuktian tindak pidana politik uang pada pemilu 2019 di wilayah hukum Bawaslu Provinsi Jambi sebagai berikut:

1) Temuan dan Laporan

Mengenai temuan dan laporan tindak pidana politik uang Wein Arifin sebagai Koordinator Devisi Penindakan dan pelanggaran Bawaslu Provinsi Jambi menejelaskan "Temuan tindak pidana politik uang bersumber dari pengawasan Bawaslu baik di tingkat Provinsi, tingkat Kota atau Kabupaten, tingkat Kecamatan, maupun ditingkat Desa. Sedangkan Laporan berdasarkan aduan masyarakat secara tertulis." ${ }^{5} \mathrm{Hal}$ ini sesuai dengan rumusan ayat (2) Pasal 454 Undang-Undang Nomor 7 tahun 2017 tentang Pemilihan Umumu yang berbunyi: "Temuan pelanggaran Pemilu merupakan hasil pengawasan aktif Bawaslu, Bawaslu Provinsi, Bawaslu Kabupaten/Kota, Panwaslu Kecamatan, Panwaslu Kelurahan/Desa, Panwaslu LN, dan Pengawas TPS pada setiap tahapan penyelenggaraan Pemilu".

4 Wawancara dengan Wein Arifin, Koordinator Devisi Penindakan Pelanggaran Bawaslu Provinsi Jambi

5 Wawancara dengan Wein Arifin, Koordinator Devisi Penindakan Pelanggaran Bawaslu Provinsi Jambi 
Temuan tindak pidana politik uang dituangkan dalam formulir B.2. berdasarkan hasil pengawasan pengawas pemilu setelah dibahas dan diputuskan dalam rapat pleno dengan muatan formulir sesuai dengan yang dirumuskan dalam Pasal 4 Ayat (3), sebagai berikut:

(3) Formulir sebagaimana yang dimaksud pada ayat (2) memuat paling sedikit:

a. Pengawas pemilu yang menemukan dugaan pelanggaran;

b. Batas waktu temuan;

c. Pihak terlapor, dan

d. Peristiwa dan uraian kejadian.

Penanganan Laporan Tindak Pidana Pemilu diatur dalam Pasal 7 Peraturan Bawaslu tahun 2018 membatasi waktu untuk melapor "Laporan dugaan pelanggaran pemilu disampaikan kepada pengawas pemilu paling lama 7 (tujuh) hari sejak diketahui terjadinya dugaan pelanggaran pemilu." Laporan disampaikan secara tertulis sebagaimana diatur Undang-Undang Nomor 7 Tahun 2017 tentang Pemilihan Umum dalam Pasal 454 ayat (4) menentukan:

Laporan pelanggaran Pemilu sebagaimana dimaksud pada ayat (1) dan ayat (3) disamapaikan secara tertulis dan paling sedikit memuat:

a. Nama dan alamat pelapor,

b. Pihak terlapor,

c. Waktu dan tempat kejadian perkara, dan

d. Uraian kejadian.

2) Pembahasan Pertama di Gakkumdu

Wein Arifin menjelaskan bahwa "Pembahasan Pertama bertujuan Untuk menyimpulkan apakah Laporan dan Temuan memenuhi syarat formil dan materil". ${ }^{6}$ Hal ini sesuai dengan Peraturan Bawaslu Nomor 9 tahun 2018 tentang Sentra Penegakan Hukum Terpadu dalam Pasal 19 yang menentukan sebagai berikut:

(1) Pengawas Pemilu bersama Penyidik dan Jaksa paling lama 1x24 (satu kali dua puluh empat) jam melakukan pembahasan pertama terhitung sejak tanggal temuan atau laporan diterima dan diregistrasi oleh pengawas pemilu.

(2) Pembahasan sebagaimana yang dimaksud pada ayat (1) dipimpin oleh Koordinator Gakkumdu di setiap tingkatan.

(3) Pembahasan sebagaimana yang dimaksud ayat (1) dilakukan untuk memastikan keterpenuhan syarat formil dan syarat materiil temuan atau laporan dugaan tindak pidana Pemilu yang telah diterima dan diregistrasi oleh Pengawas Pemilu.

(4) Berdasarkan hasil pembahasan sebagaiamana yang dimaksud (3), Pengawas Pemilu, Penyidik, dan Jaksa menindaklanjuti dengan menyusun kajian atau melaksanakan penyelidikan atas temuan atau laporan dugaan tindak pidana Pemilu.

6 Wawancara dengan Wein Arifin, Koordinator Devisi Penindakan Pelanggaran Bawaslu Provinsi Jambi 
(5) Hasil pembahasan sebagaimana yang dimaksud pada ayat (3) dituangkan dalam Berita Acara Pembahasan I yang ditandatangani oleh Pengawas Pemilu, Penyidik, dan Jaksa.

Syarat formil dan materil dapat dilihat dalam Peraturan Badan Pengawas Pemilu Nomor 7 tahun 2018, dalam Pasal 9 meliputi:

a. Identitas pelapor/pihak yang berhak melaporkan;

b. Pihak terlapor;

c. Waktu pelaporan tidak melibi ketentuan waktu paling lama 7 (tujuh) hari sejak diketahui terjadinya dan/atau ditemukannya dugaan pelanggaran pemilu;

d. Kesesuaian tanda tangan dalam formulir laporan dugaan pelanggaran dengan Kartu Tnda Penduduk Elektronik (e-KTP) dan/atau kartu identitsa lain.

Syarat materil dalam Peraturan Badan Pengawas Pemilu meliput:

a. Peristiwa dan uraian kejadian;

b. Tempat peristiwa terjadi;

c. Saksi yang mengetahui peristiwa tersebut;

d. Bukti.

Koordinator Devisi Penindakan Pelanggaran Bawaslu Provinsi Jambi Bapak Wein Arifin, S.IP, M.IP, menyatakan "Bahwa di pembahasan pertama dilakukan kajian pelanggaran pemilu dan penyelidik melakukan penyelidikan atas temuan dan laporan. Jika Bawaslu membutuhkan keterangan tambahan Dalam kajian pelanggaran pemilu bawaslu dapat mengundang terlapor, saksi dan ahli untuk diminta keterangan tambahan. Hasil pembahasan tersebut dituangkan dalam Berita Acara Pembahasan I (satu) yang ditandatangani oleh Pengawas Pemilu, penyidik, dan Jaksa."7

Kitab Undang-Undang Hukum Acara Pidana (KUHAP) Pasal 1 angka 5 bahwa "Penyelidikan adalah serangkaian tindakan penyelidik untuk mencari dan menemukan suatu suatu peristiwa yang diduga sebagai tindak pidana guna menentukan dapat atau tidaknya dilakukan penyidikan menurut cara yang diatur dalam undang-undang ini." Di Pasal 4 KUHAP dijelaskan bahwa "Penyelidik yang dimaksud adalah setiap pejabat Polisi Negara Republik Indonesia." Kemudian pada Pasal 5 KUHAP menyebutkan kewenangan Penyelidik sebagai berikut:

a. Karena kewajiban mempunyai wewenang:

1. Menerima laporan atau pengaduan dari seseorang tentang adanya tindak pidana;

2. Mencari keterangan dan barang bukti;

3. Menyurih berhenti seseorang yang dicurigai dan menanyakan serta memeriksa tanda pengenal diri;

7 Wawancara dengan Wein Arifin, S.IP, M.IP., Koordinator Devisi penindakan Pelanggaran Bawaslu Provinsi Jambi, tanggal 14 Desember 2019 
4. Mengadakan tindakan lain menurut hukum yang bertanggung jawab.

b. Atas perintah penyidik dapat melakukan tindakan:

1. Penangkapan, larangan meninggalkan tempat, penggeledahan dan penyitaan;

2. Pemeriksaan dan penyitaan surat

3. Mengambil sidik jari dan memotret seseorang;

4. Membawa dan mengahadapkan seorang pada penyidik.

Dalam Pasal 479 Undang-Undang Nomor 7 Tahun 2017 Tentang Pemilu menentukan bahwa "Penyelidik dalam melakukan penyelidikan menemukan bukti permulaan yang cukup tentang adanya dugaan tindak pidana pemilu, hasil penyelidikannya disertai berkas perkara disampaikan kepada penyidik paling lama 1x24 (satu kali dua puluh empat) jam." Bukti permulaan yang cukup dalam tindak pidana pemilu sesuai dengan Pasal 184 Kitab Undang-Undang Hukum Acara Pidana, hal ini disampaikan oleh Wein Arifin sebagai Koordinator Devisi Penindakan Pelanggaran Bawaslu Provinsi Jambi "Ada lima alat bukti dalam tindak pidana pemilu yaitu saksi, saksi ahli, surat petunjuk, dan keterangan terdakwa yang sesuai pengaturan di dalam KUHAP." ${ }^{8}$

Wein Arifin menejelaskan mengenai kajian pada pembahasan pertama "sebelum pembahasan dilakukan Pemeriksaan dengan klarifikasi terhadap pelapor, terlapor, saksi, pihak terkait dan meminta keterangan ahli untuk dituangkan dalam berita acara"

Sebagaimana diatur dalam Pasal 18 Peraturan Bawaslu Nomor 7 Tahun 2018, yaitu sebagai berikut:

(1) Dalam proses pengkajian temuan dan laporan dugaan pelanggaran Pemilu, Bawaslu, Bawaslu Provinsi, Bawaslu Kabupaten/Kota, Panwaslu Kecamatan, dan Panwaslu LN dapat melakukan klarifikasi terhadap pelapor, pihak yang diduga sebagai pelaku pelanggaran, saksi, atau ahli untuk didengar keterangannya.

(2) Keterangan yang disampaikan oleh perlapor, terlapor/prlaku, saksi, dan/atau ahli dituangkan kedalam berita acara klarifikasi sebagaimana formulir berita acara klarifikasi yang dituangkan dalam formulir model B.9.

(3) Klarifikasi dan/atau permintaan keterangan dilakukan oleh Bawaslu, Bawaslu Provinsi, Bawaslu Kabupaten/kota, Panwaslu Kecamatan, dan Panwaslu LN dan/atau tim klarifikasi yang ditunjuk.

(4) Pihak-pihak yang diminta keterangan atau klarifikasi, sebelumnya diambi sumpah/janji sesuai dengan agama dan keyakinan oleh petugas yang ditunjuk serta menandatangani berita acara dibawash sumpah/janji sebagaiamana formulir keterangan/klarifikasi dibawah sumpah janji yang dituangkan dalam formulir model B.7.

3) Pembahasan Kedua di Gakkumdu

Wein Arifin menjelaskan bahwa "Pembahasan selanjutnya adalah membahas hasil kajian dan hasil penyelidikan dengan tujuan menyimpulkan

8 Wawancara dengan Wein Arifin, Koordinator Devisi penindakan Pelanggaran Bawaslu Provinsi Jambi, tanggal 14 Desember 2019. 
apakah laporan atau temuan tersebut merupakan tindak pidana pemilu atau bukan, dengan tenggang waktu paling lama 14 (empat belas) hari. Apabila disimpulkan laporan atau temuan tersebut merupakan tindak pidana pemilu maka proses dilanjutkan ketahap penyidikan. hasil pembahasan dituangkan dalam Berita Acara Pembahasan II (dua)".

Pembahasan kedua yang dijelaskan diatas sesuai dengan Peraturan Bawaslu Nomor 9 Tahun 2018 Tentang Sentra Gakkumdu dalam Pasal 22 yang menentukan:

(1) Pengawas Pemilu bersama dengan Penyidik dan Jaksa melakukan pembahasan kedua paling lama 14 (empat belas) hari kerja sejak temuan atau laporan diterima dan diregistrasi oleh Pengawas Pemilu.

(2) Pembahasan sebagaimana yang dimaksud pada ayat (1) dipimpin oleh Koordinator Gakkumdu sesuai dengan tingkatan untuk membahas kajian Pengawa Pemilu dan laporan hasil Penyelidikan.

(3) Hasil pembahasan sebagaimana yang dimaksud pada ayat (2) untuk menyimpulkan temuan atau laporan merupakan tindak pidana pemilu atau bukan tindak pidana pemilu.

(4) Apabila temuan atau laporan dugaan tindak pidana pemilu berdasarkan kesimpulan rapat menyatakan terdapat unsur dugaan tindak pidana pemilu, Pengawas Pemilu, Penyidiki, dan Jaksa melanjutkan penanganan temuan atau laporan dugaan tindak pidana pemilu pada tahap Penyidikan.

(5) Apabila temuan atau laporan dugaan tindak pidana pemilu berdasarkan kesimpulan rapat menyatakan tidak terdapat unsur tindak pidana pemilu, Pengawas Pemilu, Penyidik, dan Jaksa menghentikan penanganan temuan dan laporan.

(6) Hasil pembahasan kedua dituangkan kedalam Berita Acara Pembahasan II yang ditandatangani oleh Pengawas Pemilu, Penyidik, dan Jaksa.

4) Rapat Pleno Pengawas Pemilu

Koordinator Devisi Penindakan Pelanggaran Bawaslu Provinsi Jambi mengatakan "Sebelum kasus dinaikan ke Penyidikan, Bawaslu terlebih dahulu melakukan rapat pleno untuk memutuskan apakah kasus tersebut dihentikan atau dinaikan ke penyidikan". Rapat Pleno yang disebut diatas berdasarkan Peraturan Bawaslu Nomor 9 Tahun 2018 Tentang Sentra Gakkumdu di Pasal 23 dengan rumusan sebagai berikut:

(1) Pengawas Pemilu melaksanakan rapat pleno untuk memutuskan temuan atau laporan ditingkatkan ket tahap Penyidikan atau dihentikan.

(2) Rapat pleno sebagaimana yang dimaksud pada ayat (1) didasarkan pada hasil pembahasan kedua, kajian pengawas pemilu, dan laporan hasil penyelidikan.

(3) Dalam hal rapat pleno memutuskan temuan atau laporan penanganan pelanggaran pemilu dihentikan, pengawas pemilu mengumumkan status temuan atau laporan disertai dengan alasan penghentian dan memberi tahukan kepada pelapor.

(4) Dalam hal rapat pleno memutuskan dugaan pelanggaran pemilu ditingkatkan pada tahap Penyidikan, pengawas pemilu meneruskan 
temuan atau laporan kepada Penyidik dan menerbitkan surat perintah tugas untuk melaksanakan Penyidikan.

(5) Penerusan temuan atau leporan disertai dengan berkas pelanggaran yang memuat:

a. Surat pengantar;

b. Surat perintah tugas untuk melakukan Penyidikan yang dikeluarkan oleh Pengawas Pemilu;

c. Daftar isi;

d. Temuan atau laporan dugaan tindak pidana pemilu;

e. Hasil kajian;

f. Laporan hasil Penyelidikan;

g. Surat undangan klarifikasi;

h. Berita acara klarifikasi;

i. Berita acara klarifikasi dibawah sumpah;

j. Berita acara pembahasan pertama;

k. Berita acara pembahasan kedua;

l. Daftar saksi dan/atau ahli;

m. Daftar terlapor;

n. Daftar barang bukti;

o. Barang bukti; dan

p. Administrasi penyelidikan Gakkumdu dari unsur Polri.

5) Penyidikan

Setelah Penyidik menerima surat pemberitahuan penyidikan dan surat perintah penyidikan yang diterbitkan oleh Koordinaor Gakkumdu dari Unsur Polri maka status pemeriksaan ditingkatkan ke tahap penyidikan. Sebagaimana yang disampaikan oleh Wein Arifin "setelah penyelidik menyusuri dan memastikan bahwa hal tersebut benar-benar merupakan tindak pidana pemilu sesuai dengan alat bukti dan petunjuk maka proses selanjutnya di tingkatkan ke tahap penyidikan".

Penyidikan dalam Kitab Undang-Undang Hukum Acara Pidana di Pasal 1 angka 2 adalah serangkaian tindakan penyidik dalam hal dan menurut cara yang diatur dalam undang-undang ini untuk mencari serta mengumpulkan bukti yang dengan bukti itu membuat terang tentang tindak pidana yang terjadi dan guna menemukan tersangkanya.

Penyidik dalam tindak pidana pemilu diatur khusus dalam Pasal 478 Undang-Undang Nomor 7 Tahun 2017 Tentang Pemilu yang menentukan sebagai berikut:

Untuk dapat ditetapkan sebagai penyelidik dan penyidik tindak pidana Pemilu harus memenuhi persyaratan sebagai berikut:

a. Telah mengikuti pelatihan khusus mengenai penyelidikan dan penyidikan tindak pidana Pemilu 
b. Cakap dan memiliki integritas moral yang tinggi selama menjalankan tugasnya; dan

c. Tidak pernah dijatuhi hukuman disiplin.

Di tahap penyidikan oleh penyidik, di Pasal 7 Kitab Undang-Undang Hukum Acara Pidana penyidik berwenang karena kewajibannya melakukan halhal sebagai berikut:

a. Menerima laporan atau pengaduan dari seorang tentang adanya tindak pidana;

b. Melakukan tindakan pertama pada saat ditempat kejadian;

c. Menyuruh berhenti seorang tersangka dan memeriksa tanda pengenal diri tersangka;

d. Melakukan penangkapan, penahanan, penggeledahan dan penyitaan;

e. Melakukan pemeriksaan dan penyitaan surat;

f. Mengambil sidik jari dan memotret seseorang;

g. Memanggil orang untuk didengar dan diperiksa sebagai tersangka atau saksi;

h. Mendatangkan orang ahli yang diperlukan dalam hubungannya dengan pemeriksaan perkara;

i. Mengadakan penghentian penyidikan;

j. Mengadakan tindakan lain menurut hukum yang bertanggung jawab.

Setelah penyidik melakukan penyidikan berdasarkan pasal 480 Ayat (1) Undang-Undang Nomor 7 Tahun 2017 Tentang Pemilahan Umum bahwa penyidik menyampaikan hasil penyidikannya beserta berkas perkara kepada penuntut umum paling lama 14 (empat belas) hari sejak diterimanya laporan dan dapat dilakukan tanpa kehadiran tersangka.

6) Pembahasan Ketiga di Gakkumdu

Wein Arifin menjelaskan tentang pembahasan tahap tiga "Pada pembahasan tahap tiga dilakukan selama proses penyidikan yang dipimpin oleh Koordinator Gakkumdu dari unsur Polri dengan agenda pembahasan laporan hasil penyidikan apabakah perkara tersebut memenuhi unsur maka dilimpahkan kepada penuntut dan jika tidak maka perkara dihentikan". ${ }^{9}$

Peraturan Bawaslu Nomor 9 Tahun 2018 Tentang Sentra Gakkumdu merumuskan pembahasan ketiga di Gakkumdu dalam Pasal 25 yang menetukan:

(1) Penyidik menyampaikan hasil penyidikan dalam pembahasan ketiga yang dipimpin oleh Koordinator Gakkumdu dari unsur Polri.

(2) Pemabahsan ketiga yang sebagaimana yang dimaksud pada ayat (1) dilakukan selama proses penyidikan.

(3) Pembahasan ketiga dihadiri oleh Pengawas Pemilu, Penyidik tindak pidana pemilu, dan Jaksa untuk membahas hasil penyidikan.

(4) Pembahasan ketiga menghasilkan kesimpulan pelimpahan kasus kepada Jaksa.

9 Wawancara dengan Wein Arifin, S.IP, M.IP., Koordinator Devisi penindakan Pelanggaran Bawaslu Provinsi Jambi, tanggal 14 Desember 2019. 
(5) Hasil pembahasan ketiga dituangkan dalam Berita Acara Pembahasan III yang ditandatangani oleh Pengawas Pemilu, Penyidik tindak pidana pemilu, dan Jaksa.

Pembahasan ketiga dalam menyimpulkan apakah perkara tersebut merupakan tindak pidana pemilu atau bukan maka perlu kita lihat unsur-unsur didalam pasal yang mengatur tindak pidana pemilu. Disini penulis memfokuskan pada tindak pidana pemilu politik uang, maka perlu kita ketahui unsur-unsur tindak pidana politik uang dalam pasal-pasal yang mengatur tentang tindak pidana politik uang pada pemilu 2019 sebagai berikut:

1. Pasal 515 menentukan: Setiap orang yang dengan sengaja pada saat pemungutan suara menjanjikan atau memberikan uang atau materi lainnya kepada Pemilih supaya tidak menggunakan hak pilihnya atau memilih peserta atau menggunakan hak pilihnya dengan cara tertentu sehingga surat suaranya tidak sah, dipidana dengan pidana penjara paling lama 3 (tiga) tahun dan denda paling banyak Rp36.000.000,00 (tiga puluh enam juta rupiah). Dalam pasal diatas dapat kita simpulkan unsur-unsur yang harus dipenuhi adalah sebagai berikut:

1) Setiap orang dengan sengaja atau dengan niat,

2) Memberikan uang atau materi lainnya kepada Pemilih,

3) Pada waktu pemungutan suara,

4) Dengan tujuan pemilih menggunakan hak pilihnya atau memilih calon tertentu atau memilih dengan cara tertentu atau agar surat suaranya tidak sah.

2. Pasal 523 Ayat (1) menentukan: Setiap pelaksana, peserta, dan/atau tim Kampanye Pemilu yang dengan sengaja menjanjikan atau memberikan uang atau materi lainnya sebagai imbalan kepada peserta kampanye pemilu secara langsung ataupun tidak langsung sebagaimana dimaksud dalam pasal 280 ayat (1) huruf j dipidana dengan pidana penjara paling lama 2 (dua) tahun dan denda paling banyak Rp24.000.000,00 (dua puluh empat juta rupiah). Unsur yang harus dipenuhi dalam ayat ini adalah sebagai berikut:

1) Dengan sengaja atau dengan niat

2) Pada masa kampanye

3) Pelaksana Pemilu, Peserta Pemilu, dan/atau tim Kampanye

4) Menjanjikan atau memberikan uang atau materi lainnya

5) Langsung atau tidak langsung kepada peserta kampanye

3. Pasal 523 Ayat (2) menentukan: setiap pelaksana, peserta, dam/atau tim kampanye pemilu yang dengan sengaja pada masa tenang menjanjikan atau memberikan imbalan uang atau materi linnya kepada pemilih secara langsung ataupun tidak langsung sebagaimana dimaksud dalam pasal 278 ayat (2) dipidana dengan pidana penjara paling lama 4 (empat) tahun dan denda paling banyak Rp48.000.000,00 (empat puluh delapan juta rupiah). Dapat disimpulkan unsur-unsur yang harus dipenuhi dalam pasal ini adalah sebagai berikut:

1) Dengan sengaja atau dengan niat

2) Pelaksana, peserta, dan/atau tim kampanye 
3) Pada masa tenang

4) Menjanjikan atau memberikan imbalan uang atau materi lainnya

5) Secara langsung ataupun tidak langsung kepada pemilih

4. Pasal 523 Ayat (3) menentukan "Setiap orang yang dengan sengaja pada hari pemungutan suara menjanjikan atau memberikan uang atau materi lainnya kepada pemilih untuk tidak menggunakan hak pilihnya atau memilih peserta pemilu tertentu dipidana dengan pidana penjara paling lama 3 (tiga) tahun dan denda paling banyak Rp36.000.000,00 (tiga puluh enam juta rupiah)." Unsur-unsur yang harus dipenuhi dalam pasal ini adalah sebagai berikut:

1) Dengan sengaja atau dengan niat

2) Pada hari pemungutan suara

3) Menjanjikan atau memberikan uang atau materi lainnya kepada pemilih

4) Dengan tujuan pemilih tidak menggunakan hak pilihnya atau memilih peserta pemilu tertentu.

\section{7) Penuntutan}

Wein Arifin selaku Koordinator Devisi Penindakan Pelanggaran Bawaslu Provinsi Jambi mengatakan "Pada tahap penuntutan tidak jauh beda dengan perkara pidana pada umumnya. Hanya saja pada tindak pidana pemilu rencana tuntutan dan surat tuntutan diwajibkan melapor ke pembina sentra Gakkumdu dari unsur kejaksaan dan berkas perkara dilimpahkan ke pengadilan tidak lebih dari lima hari".10 Pernyataan dari koordinator devisi penindakan pelanggaran Bawaslu Jambi sesuai dengan Peraturan Bawaslu Nomor 9 Tahun 2018 Tentang Sentra Gakkumdu di Pasal 28 tentang penuntutan menjelaskan sebagai berikut:

(1) Penuntut umum melimpahkan berkas perkara kepada Pengadilan Negeri paling lama 5 (lima) hari terhitung sejak berkas perkara diterima dari penyidik dan surat pengantar pelimpahan yang ditandatangani oleh Pembina Gakkumdu dari unsur Kejaksaan sesuai dengan tingkatan.

(2) Penuntut umum membuat rencana dakwaan dan surat dakwaan.

(3) Penuntut umum menyusun rencana penuntutan dan membuat rencana penuntutan.

(4) Penuntut umum melapor rencana dakwaan dan surat dakwaan dan/atau rencana tuntutan dan surat tuntutan sebagaimana dimaksud pada ayat (2) dan ayat (3) kepada pembina Sentra Gakkumdu dari unsur kejaksaan sesuai dengan tingkatan.

(5) Surat dakwaan sebagaimana yang dimaksud pada ayat (2) tembusannya disampaikan kepada Koordinator Gakkumdu.

Kitab Undang-Undang Hukum Acara Pidana Pasal 1 angka 7 menjelaskan bahwa: "Penuntutan adalah tindakan penuntut umum untuk melimpahkan perkara pidana ke Pengadilan Negeri yang berwenang dalam hal dan menurut cara yang diatur dalam undang-undang ini dengan permintaan supaya diperiksa

10 Wawancara dengan Wein Arifin, S.IP, M.IP., Koordinator Devisi penindakan Pelanggaran Bawaslu Provinsi Jambi, tanggal 14 Desember 2019. 
dan diputus oleh hakim di sidang Pengadilan." Di proses penuntutan yang berwenang melakukan penuntutan adalah penutut umum yaitu jaksa yang berwenang, kewenangan ini didasarkan pada Pasal 13 Kitab Undang-Undang Hukum Acara Pidana. Penuntut umum dalam proses penuntutan di Pasal 14 Kitab Undang-Undang Hukum Acara Pidana menentukan:

Penuntut Umum diberi wewenang melakukan:

a. Menerima dan memeriksa berkas perkara penyidikan dari prnyidik atau penyidik pembantu;

b. Mengadakan prapenuntutan apabila ada kekurangan pada penyidikan dengan memperhatikan ketentuan pasal 110 ayat (3) dan ayat (4), dengan memberi petunjuk dalam rangka penyempurnaan penyidikan dari penyidik;

c. Memberikan perpanjangan penahanan, melakukan penahanan atau penahanan lanjutan dan atau mengubah status tahanan setelah perkaranya dilimpahkan oleh penyidik;

d. Memberikan surat dakwaan;

e. Melimpahkan perkara kepengadilan;

f. Menyampaikan pemberitahuan kepada terdakwa tentang ketentuan hari dan waktu perkara disidangkankan yang disertai surat penggilan, baik kepada terdakwa maupun kepada saksi, untuk datang pada sidang yang ditentukan;

g. Melakukan penuntutan;

h. Menutup perkara demi kepentingan hukum;

i. Mengadakan tindakan lain dalam lingkup tugas dan tanggung jawab sebagai penuntut umum menurut ketetntuan undang-undang ini;

j. Melaksanakan penetapan hakim.

Dapat disimpulkan di penuntutan ada beberapa proses dalam perkara pidana. Pertama, penuntut umum menerima dan memeriksa berkas perkara oleh penyidik. Kedua, mengadakan prapenuntutan dalam hal hasil penyidikan belum lengkap. Dalam perkara tindak pidana pemilu diatur di Pasal 480 Ayat (2) Undang-Undang Pemilu bahwa: "dalam hal hasil penyidikan belum lengkap, dalam waktu paling lama 3 (tiga) hari penuntut umum mengembalikan berkas perkara kepada penydik kepolisian disertai petunjuk tentang hal yang harus dilakukan untuk dilengkapi". Dilanjutkan di ayat (3) bahwa penyidik kepolisian dalam waktu paling lama 3 (tiga) hari harus sudah menyampaikan kembali berkas perkara tersebut kepada penuntut umum. Ketiga, penutut umum melimpahkan perkara ke pengadilan. Undang-Undang Nomor 7 Tahun 2017 Tentang Pemilu di Pasal 480 Ayat (4) menentukan bahwa: "Penuntut umum melimpahkan berkas perkara kepada Pengadilan Negeri paling lama 5 (lima) hari sejak menerima berkas perkara dan dapat dilakukan dengan tanpa kehadiran tersangka. Keempat, setelah penuntutan di pengadilan, penuntut umum melaksanakan penetapan hakim."

Setelah Penuntut Umum menerima pelimpahan berkas perkara dari penyidik dan surat pengantar pelimpahan Penuntut umum membuat rancana dakwaan dan surat dakwaan kemudian melaporkan kembali kepada pembina Sentra Gakkumdu dari unsur kejaksaan dan Koordinator Gakkumdu. 
8) Pengadilan

Mengadili adalah serangkaian tindakan Hakim untuk menerima, memeriksa dan memutus perkara pidana berdasarkan asas bebas, jujur dan tidak memihak di sidang Pengadilan dalam hak dan menurut cara yang diatur dalam undang-undang ini. Dalam hal mendali tindak pidana politik uang, bapak Asnawai R, M.Pd, menyampaikan "Perkara politik uang diadili di Pengadilan Negeri setempat sebagai pengadilan tingkat pertama. jika terdakwa atau penuntut umum tidak menerima putusan pengadilan negeri maka dapat dilakukan upaya hukum banding di Pengadilan Tinggi. Berbeda dengan tindak pidana pada umumnya, tindak pidana pemilu hanya sampai di pengadilan tinggi yang berarti tidak ada upaya hukum seperti kasasi". ${ }^{11}$ Tidak dapatnya melakukan upaya lagi setelah putusan pengadilan tinggi juga dijelaskan dalam UndangUndang Nomor 7 Tahun 2017 Tentang Pemilu di Pasal 482 Ayat (2) yang menenentukan bahwa "Putusan pengadilan tinggi sebagaimana dimaksud pada ayat (4) merupakan putusan terakhir dan mengikat serta tidak dapat dilakukan upaya hukum lain".

Pengadilan Negeri dalam memeriksa, mengadili, dan memutus perkara tindak pidana pemilu diberi waktu paling lama 7 (tujuh) hari setelah pelimpahan berkas perkara sebagaimana diatur dalam Pasal 482 Ayat (1) Undang-Undang Pemilu. Kemudian dilanjutkan di Ayat (2) menyatakan dalam hal putusan pengadilan sebagaimana dimaksud pada Ayat (1) diajukan banding, permohonan banding diajukan paling lama 3 (tiga) hari setelah putusan dibacakan dan pengadilan negeri diberi waktu paling lama 3 (hari) melimpahkan berkas perkara permohonan banding kepada pengadilan tinggi setelah permohonan banding diterima sebagaimana dimaksudkan dalam ayat (3) di pasal tersebut.

Dalam hal pemeriksaan, mendali dan memutus perkara tindak pidana dilakukan oleh majelis khusus tindak pidana sebagaimana ditentukan dalam Pasal 481 Ayat (2) bahwa "sidang pemeriksaan tindak pidana pemilu sebagaiamana dimaksud pada ayat (1) dilakukan oleh majelis khusus". Mejelis khusus dalam menangani tindak pidana pemilu yang dimaksud adalah hakim karier pada pengadilan negeri dan pengadilan tinggi yang ditetapkan secara khusu untuk memeriksa, mengadili, dan memutus perkara tindak pidana pemilu yang ditetapkan berdasarkan keputusan Ketua Mahkamah Agung Republik Indonesia sebagaimana diatur di Pasal 485 Ayat (1) dan Ayat (2) Undang-Undang Pemilu.

Hakim khusus yang dimaksud harus memenuhi syarat sebagaiamana diatur di Pasal 485 Undang-Undang Tentang Pemilu sebagai berikut:

1. Telah melaksanakan tugas sebagai hakim minimal 3 (tiga) tahun, kecuali tidak ada hakim lain yang memenuhi syarat;

2. hakim tersebut dibebaskan dari tugasnya untuk memeriksa, mengadili, dan memutuskan perkara lain;

3. harus menguasai pengetahuan tentang Pemilu.

11 Wawancara dengan Asnawi R, M.Pd., Ketua Bawaslu Provinsi Jambi, tanggal 5 Desember 2019. 
9) Pembahasan Keempat di Gakkumdu

Wein Arifin sebagai Koordinator Devisi Penindakan Pelanggaran Bawaslu Provinsi Jambi menjelaskan "Setelah perkara tindak pidana pemilu diputuskan oleh Pengadilan Negeri, selanjutnya Gakkumdu melakukan pembahasan keempat dengan tujuan untuk menentukan apakah melaksanakan putusan pengadilan atau melakukan upaya hukum banding ke pengadilan tinggi". Hal ini sesuai dengan yang diatur dalam Pasal 29 Peraturan Bawaslu Nomor 9 Tahun 2018 Tentang Sentra Gakkumdu yakni sebagai berikut:

(1) Setelah putusan Pengadilan dibacakan, Penuntut Umum melaporkan kepada Koordinator Gakkumdu sesuai dengan tingkatan.

(2) Gakkumdu sesuai dengan tingkatan melakukan pembahasan keempat dipimpin oleh Koordinator dari unsur Kejaksaan paling lama 1x24 (satu kali dua puluh empat) jam setelah putusan pengadilan dibacakan.

(3) Pembahasan keempat sebagaimana yang dimaksud pada ayat (2) dihadiri oleh Pengawas Pemilu, Penyidik Tindak Pidana Pemilu dan Kejaksaan.

(4) Pembahasan keempat sebagaimana yang dimaksud pada ayat (2) dilaksanakan untuk menentukan sikap Gakkumdu dalam:

a. Melakukan upaya hukum terhadap putusan pengadilan:atau

b. Melaksanakan putusan pengadilan.

(5) Dalam hal hasil pembahasan keempat menentukan Gakkumdu melakukan upaya hukum sebagaimana yang dimaksud pada ayat (3) huruf a, penuntut umum mengajukan banding dan memori banding paling lama 3 (tiga) hari setelah putusan dibacakan.

(6) Dalam hal terdakwa melakukan upaya hukum banding terhadap putusan pengadilan, Penuntut umum membuat kontra memori banding.

Jika pembahasan menyimpulkan tidak melakukan upaya hukum banding maka Jaksa melaksanakan putusan Pengadilan dengan jangka waktu paling lama 3 (tiga) hari setelah putusan dibacakan serta dapat didampingi oleh Penyidik dan Pengawas Pemilu ketentuan ini didasarkan pada aturan yang dirumuskan dalam Pasal 30 di Peraturan Bawaslu Nomor 9 Tahun 2018 Tentang Sentra Gakkumdu.

\section{Faktor Penghambat Badan Pengawas Pemilu (Bawaslu) Provinsi Jambi Dalam Menangani Tindak Pidana Politik Uang Pada Pemilu 2019}

Dalam proses menangani tindak pidana politik uang pada Pemilu 2019 di Provinsi Jambi terdapat hambatan dalam membuktikan perkara tersebut. Asnawi R, sebagai Ketua Bawaslu Provinsi Jambi menjelaskan:

Kendala yang kami hadapi dalam membuktikan tindak pidana politik uang pada pemilu 2019 adalah:

1. Masyarakat kita masih apatis. Sehingga sedikitnya laporan dan temuan.

2. Minimnya alat bukti dalam setiap laporan atau temuan sehingga membuat perkara tersebut tidak memenuhi unsur.

3. Lembaga Sentra Gakkumdu. Dalam beberapa kasus yang menurut Bawaslu memenuhi unsur namun tidak demikian dengan Sentra 
Gakkumdu dari sisi Kepolisian dan Kejaksaan yang berpendapat tidak memenuhi unsur.

4. Tidak ada Kewenangan penyadapan. Dengan cara menyadap komunikasi antara pelaku dan penerima sehingga dapat terungkap.

5. Sulitnya pembuktian dalam hal tertangkap tangan. Dalam suatu kasus ada pihak yang dicurigai ingin melakukan politik uang. Tapi tetap tidak bisa dibuktikan meskipun uangnya ada tapi kita tidak bisa membuktikan apakah niatnya melakukan politik uang dan juga belum ada transaksi sehingga kasus tersebut dihentikan. ${ }^{12}$

Selanjutnya dijelaskan oleh Wein Arifin sebagai Koordinator Penindakan Pelanggaran Bawaslu Provinsi Jambi:

Adapun hambatan Bawaslu dalam proses pembuktian tindak pidana politik uang pada pemilu 2019 adalah:

1. Pengaturan jangka waktu yang terbatas dalam menangani tindak pidana

2. Dikarenakan jangka waktu yang terbata, berdampak pada pemenuhan alat bukti.

3. Karangka pengaturan. Misalnya dalam satu pasal menyatakan tim kampanye, faktanya yang bersangkutan bukan tim kampanye, karena tim kampanye harus di SK kan oleh caleg atau Partai Politik. Misalnya pelakunya saudaranya,temannya atau individu lain yang tidak ada SK sehingga tidak memenuhi unsur. ${ }^{13}$

Berdasarkan penjelasan para anggota Bawaslu, dari hambatan yang dialami juga berimbas dalam hal pembuktian. Adapun masalah yang ada dalam hal pembuktian adalah:

1. Masyarakat Apatis

Apatis adalah sikap acuh tak acuh, masa bodoh, ataupun tidak peduli. ${ }^{14}$ Dalam Pemilu masyarakat yang tidak peduli disebabkan karena ketidakyakinan adanya perubahan yang akan terjadi setelah diselenggarakannya pemilu. Hal ini malah memperburuk keadaan yang membuat pihak yang tidak layak terpilih menjadi terpilih. Khususnya dalam Politik Uang (Money politic) maka yang terpilih adalah calon yang bermodal. Disadari atau tidak calon yang telah mengeluarkan modal tentunya akan mengambil kembali modalnya dengan cara korupsi. Sehingga menurut penulis bersihnya Pemilu dari politik uang sangat berdampak pada tindak pidana korupsi.

2. Kurangnya Alat bukti

Sulitnya mencari alat bukti dalam kasus politik uang sangat berdampak pada pembuktian perkara politik uang. Jenis-jenis alat bukti diatur dalam Pasal 184 ayat (1) Kitab Undang-Undang Hukum Acara Pidana, yaitu:

Alat bukti yang sah ialah:

12 Wawancara dengan Asnawi, Ketua Bawaslu Provinsi Jambi, tanggal 5 Desember 2019.

13 Wawancara dengan Wein Arifin, S.IP, M.IP., Koordinator Devisi penindakan Pelanggaran Bawaslu Provinsi Jambi, tanggal 14 Desember 2019

14 Renati W. Rosari, Kamus PPKn, Aksara Sinergi Media, Surakarta, 2013, hlm 10. 

a. Keterangan saksi;
b. Keterangan ahli;
c. Surat;
d. Petunjuk;
e. Keterangan terdakwa.

Jika didasarkan pada pasal diatas dalam hal tindak pidana politik uang maka timbul beberapa pertanyaan siapa yang menjadi saksi ketika transaksi antara pemberi dan penerima saja di lokasi, kemudian surat yang bagaimana sebagai bukti, mungkinkah terdakawa mau mengakui politik uang. Pertanyaan diatas tentunya menyulitkan Bawaslu dalam pembuktian tindak pidana politik uang. Pada saat wawancara dengan Asnawi sebagai Ketua Bawaslu Provinsi Jambi mengatakan "Sulitnya mencari alat bukti dalam politik uang sehingga menurut saya perlunya kewenangan penyadapan. Karena dengan menyadap kita bisa tau komunikasi antara pemberi dan penerima sehingga dapat membantu dalam menangkap pelaku. Kemudian penyadapan juga bisa menjadi bukti yang tidak bis dikelak lagi sama halnya pada kasus korupsi yang kebanyakan kasus dibuktikan dengan operasi tangkap tangan sehingga bukti yang dipegang Komisi Pemberantas Korupsi (KPK) kuat karena pada operasi tersebut biasanya akan ketangkap penerima dan pemberi dan ada alat bukti uang." 15

3. Sentra Penegakkan Hukum Terpadu (Gakkumdu)

Gakkumdu yang tujuan dibentuknya untuk menyamakan pemahaman dan pola penanganan tindak pidana pemilu sebagaimana yang diatur dalam pasal 486 Undang-Undang nomor 7 tahun 2017 tentang Pemilihan Umum malah menimbul perdebatan dalam setiap pembahasan sebagaimana yang disampaikan Ketua Bawaslu Provinsi Jambi diatas karena perbedaan pendapat yang menurut bawaslu memenuhi unsur tetapi bagi kepolisian atau kejaksaan tidak memenuhi unsur sehingga banyak kasus yang dihentikan. Perlu atau tidaknya Gakkumdu sangat perlu dipertimbang karena Kepolisian dan Kejaksaan didalam Gakkumdu berada dalam tahap yang berbeda dan dengan fumgsi yang berbeda pula. Kepolisian ditahap penyelidikan dan penyidikan serta Kejaksaan ditahan penuntutan, jelas sekali perbedaan kewenangan dan fungsi dari masingmasing instansi antara Pengawas Pemilu dengan Kepolisian dan Kejaksaan.

4. Jangka waktu yang terlalu singkat

Waktu yang diberikan kepada Bawaslu selama 14 (empat belas) hari untuk menyimpulkan laporan atau temuan merupakan tindak pidana pemilu atau bukan tindak pidana yang berdasarkan Pasal 22 Perbawaslu nomor 9 tahun 2018. Terlalu singkat waktu yang diberikan maka tidak efektifnya dalam setiap proses. hal ini juga dikomentari oleh bapak Wein Arifin, "Penanganan temuan dan laporan tindak pidana politik uang yang

15 Wawancara dengan Asnawi R, M.Pd., Ketua Bawaslu Provinsi Jambi, tanggal 5 Desember 2019. 
tidak ada satupun kasus yang naik ke pengadilan tentunya ada pengaruh terhadap batasan waktu dalam proses pembuktian". 16

Jangka waktu yang terlalu singkat sangat bertantangan dengan asas peradilan cepat, sederhana, dan biaya ringan. Dengan dibatasi waktu dalam proses penanganan perkar tindak pidana pemilu membuat penegak hukum seakan-akan tegesa-gesa sihingga bisa membuat hasil tidak sesuai dengan seharusnya.

5. Kerangka pengaturan

Sulitnya memenuhi unsur dalam kerangka yang di atur Pasal poltik uang membuat politik uang masih berkembang dimasyarakat. Seperti pada Undang-Undang Nomor 7 Tahun 2017 tentang Pemilu yang mengatur tentang politik uang di pasal 523 yang membatasi pada setiap pelaksana, peserta, tim kampanye bisa kita ketahui orang yang dapat dikenakan pasal tersebut adalah:

1) Pelaksana Pemilu

Dalam Pasal 1 angka 8 Undang-Undang Pemilu menyebutkan "Komisi Pemilihan Umum yang selanjutnya disingkat KPU adalah lembaga penyelenggara Pemilu yang bersifat nasional, tetap, dan mandiri dalam melaksanakan Pemilu". Dapat disimpulkan pelaksana yang dimaksud adalah Komisi Pemilihan Umum (KPU).

2) Peserta Pemilu

Dalam Pasal 1 angka 27 menyebutkan bahwa "Peserta Pemilu adalah partai politik untuk pemilu anggota DPR, anggota DPRD Provinsi, anggota DPRD Kabupaten/Kota, perseorangan untuk pemilu anggota DPD, dan pasangan calon yang diusulkan oleh partai politik atau gabungan partai politik untuk Pemilu Presiden dan Wakil Presiden". Sehingga disimpulka Peserta Pemilu dimaksud adalah calon yang akan kita pilih.

3) Tim Kampanye

Dalam Peraturan KPU Nomor 28 Tahun 2018 tentang perubahan atas Peraturan KPU Nomor 23 Tahun 2018 tentang Kampanye Pemilihan Umum di Pasal 1 angka 23 menjelaskan "Tim Kampanye adalah tim yang dibentuk oleh pasangan calon bersamasama dengan partai politik atau gabungan partai politik yang mengusulkan pasangan calon, yang didaftarkan ke KPU dan bertanggung jawab atas pelaksanaan teknis penyelenggaraan kampanye". Dapat disimpulkan bahwa tim kampanye yang dimaksud adalah tim yang dibentuk oleh calon dan didaftarkan ke KPU sehingga siapapun yang tidak terdaftar di KPU sebagai tim kampanye tidak dapat memenuhi unsur pasal tersebut.

Dari penjelasan diketahui bahwa orang yang bukan anggota KPU, bukan Calon, dan tidak terdaftar di KPU tidak dapat dikenakan pasal politik uang.

16 Wawancara dengan Wein Arifin, S.IP, M.IP., Koordinator Devisi penindakan Pelanggaran Bawaslu Provinsi Jambi, tanggal 14 Desember 2019. 


\section{SIMPULAN}

Proses penanganan perkara tindak pidana politik uang pada pemilu 2019 sangat panjang melalui 9 (sembilan) tahap yang setiap tahap dibatasi waktu tertentu, yaitu: Tahap temuan dan laporan, pembahasan pertama di Sentra Gakkumdu, pembahasan kedua di Sentra Gakkumdu, Rapat pleno, tahap penyidikan, pembahasan ketiga di Sentra Gakkumdu, tahap penuntutan, tahap Pengadilan, dan Pembahasan Keempat di Sentra Gakkumdu. Penghambat proses penanganan perkara tindak pidana politik uang dalam pemilu 2019 yaitu proses alur yang panjang dengan waktu yang terbatas, sehingga kesulitan dalam pemenuhan alat bukti, pentingnya kewenangan penyadapan oleh BAWASLU yang belum diatur dalam peraturan, permasalahan unsur tentang "tim kampanye"yang diatur dalam peraturan saat ini belum mampu menjerat pelaku politik uang.

\section{DAFTAR PUSTAKA}

\section{Dokumen Hukum}

Republik Indonesia. Undang-Undang Hukum Acara Pidana. Undang-Undang Nomor 8 Tahun 1981.

Republik Indonesia. Undang-Undang Kekuasaan Kehakiman. Undang-Undang Nomor 48 Tahun 2009.

Republik Indonesia. Undang-Undang Pemilihan Umum. Undang-Undang Nomor 7 Tahun 2017.

Republik Indonesia. Peraturan Komisi Pemilihan Umum Kampanye Pemilihan Umum. PKPU Nomor 28 Tahun 2018.

Republik Indonesia. Peraturan Badan Pengawas Pemilu Penanganan Temuan dan Laporan Pelanggaran Pemilihan Umum. Perbawaslu Nomor 7 Tahun 2018.

Republik Indonesia. Peraturan Badan Pengawas Pemilu Sentra Penegakan Hukum Terpadu. Perbawaslu Nomor 9 Tahun 2018.

Republik Indonesia. Peraturan Badan Pengawas Pemilu Sentra Gakkumdu. Perbawaslu Nomor 31 Tahun 2018.

\section{Buku}

Andi Hamzah. Hukum Acara Pidana Indonesia. Sinar Grafika. Jakarta, 2008.

Andi Muhammad Sofyan, Abdul Asis. Hukum Acara Pidana, Edisi Kedua. Cetakan 3. Jakarta, 2017.

Bahder Johan Nasution. Metode penelitian Ilmu Hukum. Mandar Maju. Bandung, 2008. 
Bambang Waluyo. Sistem Pembuktian Dalam Peradilan Indonesia. Sinar Grafika. Jakarta, 1991.

Eddy O.S. Hiariej.Prinsip-Prinsip Hukum Pidana. Cahaya Atma Pustaka. Yogyakarta, 2014.

Fajlurrahman Jurdi. Pengantar Hukum Pemilihan Umum. Prenadamedia Group. Cetakan. 1. Jakarta, 2018.

Hari Sasangka dan Lily Rosita. Hukum Pembuktian dalam Perkara Pidana. Mandar Maju. Surabaya, 2003.

Indra Ismawan. Pengaruh Uang Dalam Pemilu. Media Persindo. Yogyakarta, 1999.

Moch. Faisal Salam.Hukum Pidana Militer di Indonesia. Mandar Maju, bandung, 2006.

Mustafa Abdullah dan Ruben Achmad, Intisari Hukum Pidana. Ghalia Indonesia. Jakarta, 1983.

Peter Salim dan Yenny Salim. Kamus Bahasa Indonesia Kontemporer. Cetakan 2. Modern English Press. Jakarta, 1995.

R. Subekti. Hukum Pembuktian. Pradnya Paramita. Jakarta, 1991.

Renati W. Rosari. Kamus PPKn. Aksara Sinergi Media. Surakarta, 2013.

Romi Wiyanto. Penegakan Hukum Pemilu DPR, DPD, dan DPRD. Mandar Maju, 2014.

\section{Jurnal/ Majalah Ilmiah}

Dedi Irawan, "Studi Politik Uang (money politik) dalam Pemilu Legislatif tahun 2014 (Studi Kasus di kelurahan Sempaja selatan)", eJournal Ilmu Pemerintahan vol. 3 no. $4,2015$. 
Iwan Rois dan Ratna Harawati, "Urgensi Pembentukan Peradilan Khusus Pemilu dalam rangka Mewujudkan Integritas Pemilu” Jurnal Magister Hukum Udayana, vol. 7 no. $2,2018$.

Usmam dan Andi Najemi, "Mediasi Penal di Indonesia: Keadilan, Kemanfaatan, dan Kepastian Hukumnya”, Undang Jurnal Hukum Vol. 1 No. 1, 2018.

\section{Internet}

https://tirto.id/bawaslu-akui-ada-celah-politik-uang-di-pemilu-2019-c9oH. Diakses pada tanggal 14 September 2019, pukul 17.35 WIB. 